\title{
KARAKTERISASI FISIKOKIMIA NANOKALSIUM HASIL EKSTRAKSI TULANG IKAN NILA MENGGUNAKAN LARUTAN BASA DAN ASAM
}

\author{
[Physicochemical Characterization of Nano Calcium \\ from Tilapia Bone Extracted by Alkaline and Acid Solution]
}

\author{
Vanessa Lekahena ${ }^{1)^{*}}$, Didah Nur Faridah ${ }^{2)}$, Rizal Syarief2) dan R. Peranginangin ${ }^{3)}$ \\ 1) Fakultas Pertanian, Universitas Muhammadiyah Maluku Utara, Ternate \\ 2) Departemen IImu dan Teknologi Pangan, Fakultas Teknologi Pertanian, Institut Pertanian Bogor, Bogor \\ 3) Balai Besar Penelitian dan Pengembangan Pengolahan Produk dan Bioteknologi, Kementerian Kelautan dan Perikanan, Jakarta
}

Diterima 26 Maret 2013 / Disetujui 29 April 2014

\begin{abstract}
The utilization of tilapia (Oreochromis niloticus) bones as a source of natural calcium was done by alkaline (NaOH) and acid (HCl) extraction. The extraction process aims to soften the bones are milled using disc mill into nano sized calcium powder or nanocalcium. The objective of this research was to study the physicochemical properties of nanocalcium obtained from alkaline and acid extraction of tilapia bones. The results of physicochemical analysis properties of nanocalcium sample showed that nanocalcium extracted by alkaline solution had better properties than that of the untreated sample and nanocalcium extracted by acid solution. The results was indicated by the higher yield, brighter colors, smaller particle size, and calcium content (20.67\%) and phosphorus (10.09\%) with a ratio of $\mathrm{Ca} / \mathrm{P}=2.0$. The Fourier Transform Infrared (FTIR) spectra profile indicated the presence of phosphate group $\left(\mathrm{PO}_{4}{ }^{3}\right)$ at the bands of 469,563,603, 961 and $1035 \mathrm{~cm}^{-1}$, and the presence of apatite carbonate group $\left(\mathrm{CO}_{3}{ }^{2-}\right)$ was indicated by intense bands at $873,1416,1456$ and $1563 \mathrm{~cm}^{-1}$. The morphology of the sampel surface of the alkaline extracted sample was smoother, denser, and the grain size formed were relatively larger. The formed crystalline phases were HAp (hydroxyapatite), carbonate apatite type $A\left[\mathrm{Ca}_{10}\left(\mathrm{PO}_{4}\right)_{6} \mathrm{CO}_{3}\right]$ and $\mathrm{B}\left[\mathrm{Ca}_{10}\left(\mathrm{PO}_{4}\right)_{3}\left(\mathrm{CO}_{3}\right)_{3}(\mathrm{OH})_{2}\right]$ with crystalline degree of $78.4 \%$.
\end{abstract}

Keyword: extraction, nanocalcium, physicochemical properties, tilapia (Oreochromis niloticus)

\begin{abstract}
ABSTRAK
Pemanfaatan tulang ikan nila (Oreochromis niloticus) sebagai sumber kalsium alami dilakukan dengan cara ekstraksi menggunakan larutan basa $(\mathrm{NaOH})$ dan asam $(\mathrm{HCl})$. Proses ekstraksi dilakukan untuk melunakkan tulang agar mudah dalam proses penepungan menggunakan disc mill hingga menghasilkan bubuk kalsium dalam ukuran nano atau nanokalsium. Penelitian ini bertujuan untuk mempelajari karakteristik fisikokimia nanokalsium hasil ekstraksi menggunakan larutan basa dan asam dari tulang ikan nila. Hasil analisis menunjukkan bahwa sampel nanokalsium ekstraksi basa memiliki sifat yang lebih baik dibandingkan sampel bahan baku dan nanokalsium ekstraksi asam. Hasil tersebut ditunjukkan dengan rendemen yang tinggi, warna yang lebih cerah dan ukuran partikel yang lebih kecil serta kadar kalsium $(20.67 \%)$ dan fosfor $(10.09 \%)$ dengan rasio $\mathrm{Ca} / \mathrm{P}=2.09$. Hasil analisis menggunakan Fourier Transform Infrared (FTIR) menunjukkan adanya gugus fosfat $\left(\mathrm{PO}_{4}{ }^{3-}\right)$ pada pita absorpsi 469, 563, 603, 961 dan $1035 \mathrm{~cm}^{-1}$, dan apatit karbonat $\left(\mathrm{CO}_{3}{ }^{2-}\right)$ pada pita absorpsi 873, 1416, 1456 dan $1563 \mathrm{~cm}^{-1}$. Morfologi permukaan sampel ekstraksi basa terlihat lebih halus, padat dan ukuran butiran yang terbentuk relatif lebih besar. Fasa kristalin yang terbentuk adalah HAp (hidroksiapatit), apatit karbonat tipe $\mathrm{A}\left[\mathrm{Ca} 10\left(\mathrm{PO}_{4}\right)_{6} \mathrm{CO}_{3}\right]$ dan $\mathrm{B}\left[\mathrm{Ca}{ }_{10}\left(\mathrm{PO}_{4}\right)_{3}\left(\mathrm{CO}_{3}\right)_{3}(\mathrm{OH})_{2}\right]$ dengan derajat kristalinitas $78.4 \%$.
\end{abstract}

Kata kunci: ekstraksi, ikan nila (Oreochromis niloticus), nanokalsium, sifat fisikokimia

\section{PENDAHULUAN}

Produksi pengolahan ikan umumnya menghasilkan 10-15\% limbah tulang ikan dengan kandungan mineral $60-70 \%$ dalam bentuk garam anorganik terutama kalsium fosfat, kreatin fosfat dan hidroksiapatit $\left[\mathrm{Ca}_{10}(\mathrm{OH})_{2}\left(\mathrm{PO}_{4}\right)_{6}\right]$ yang merupakan bentuk kristal yang melekat pada kolagen fibril (Kim dan Mendis, 2006; Phiraphinyo et al. 2006; Malde et al. 2010; Huang et al. 2011). Kalsium tulang ikan membentuk kompleks dengan fosfor dalam bentuk apatit atau trikalsiumfosfat, merupakan mineral yang

*Penulis Korespondensi:

E-mail: enchalekahena@yahoo.com dibutuhkan oleh tubuh sebagai komponen metabolisme pada berbagai proses biokimia, fisiologis dan pemeliharan jaringan tulang (Sittikulwitit et al. 2004). Kandungan kalsium dan fosfor yang tinggi pada tulang ikan $(2 \%$ atau $20 \mathrm{~g} / \mathrm{kg}$, bk) sehingga tulang ikan dapat dimanfaatkan sebagai sumber kalsium alami untuk memenuhi asupan kalsium harian.

Berbagai kajian tentang pemanfaatan tulang ikan sebagai sumber kalsium alami telah dilakukan termasuk analisis bioavaibilitas dan potensi aplikasinya. Diantaranya ekstraksi kalsium dari tulang ikan tuna dengan metode hidrolisis protein menggunakan parameter waktu autoclaving dan frekuensi perebusan (Trilaksani, 2006); tepung tulang ikan patin sebagai sumber kalsium dan fosfor dalam pembuatan biskuit (Kaya et al. 
2007); tepung tulang ikan kakap merah dalam susu kedelai (Dongoran et al. 2007); dan tepung tulang ikan salmon, kakap dan lele pada produk roti (Luu dan Nguyen, 2009). Berdasarkan kajian tersebut tepung tulang ikan berpotensi sebagai bahan fortifikan pada produk pangan untuk memperkaya nilai gizinya.

Kalsium pada tulang sebelum difortifikasi harus diubah menjadi bentuk yang dapat dicerna. Proses ekstraksi menggunakan akuades, larutan asam dan basa, serta enzim pada suhu yang tinggi dapat merubah dan melunakkan struktur matriks tulang (Sittikulwitit et al. 2004; Kim dan Mendis, 2006 Suptijah et al. 2010). Kalsium umumnya tersedia dalam ukuran mikro $(\mu)$, yang diduga dalam proses metabolisme tubuh hanya terserap 50\% dari total kalsium yang di konsumsi (Guyton, 1987) dan salah satu alternatif untuk meningkatkan penyerapan kalsium secara maksimal dengan membentuk nanokalsium (Suptijah et al. 2010).

Nanokalsium adalah kalsium yang dihasilkan dengan memanfaatkan teknologi nano sehingga membentuk kalsium dalam ukuran yang sangat kecil (nanometer, $\mathrm{nm}$ ). Nanokalsium merupakan mineral predigestif yang sangat efiesien dalam memasuki sel tubuh karena ukuran yang super kecil menyebabkan mudah memasuki reseptor sehingga dapat terabsorpsi secara cepat dan sempurna ke dalam tubuh (Park et al. 2007). Teknologi nano adalah suatu desain, karakterisasi, produksi dan penerapan struktur, perangkat dan sistem dengan mengontrol bentuk dan ukuran pada skala nanometer (Park, 2007). Aplikasi teknologi nano dalam bahan pangan meliputi peningkatan rasa, warna, flavor, tekstur dan konsistensi produk pangan, serta meningkatkan penyerapan, bioavailabilitas nutrisi dan senyawa bioaktif (Greiner, 2009).

Sintesis nanomaterial dapat dilakukan secara top down dan bottom up. Top down merupakan pembuatan struktur nano dengan memperkecil ukuran material, sedangkan bottom-up adalah dengan cara merangkai atom atau molekul dan menggabungkannya melalui reaksi kimia untuk membentuk struktur nano Greiner, 2009). Metode top down adalah teknik pembentukan nanopartikel dengan proses penggilingan menggunakan milling, sedangkan metode bottom up adalah pembentukan menggunakan teknik sol-gel, presipitasi kimia, dan aglomerasi fasa gas (Uskokovic, 2007). Penelitian ini menggunakan metode top down melalui proses penggilingan menggunakan milling.

Penelitian ini bertujuan untuk mempelajari karakteristik fisikokimia nanokalsium hasil ekstraksi menggunakan larutan basa (NKEB) dan asam (NKEA) dari tulang ikan nila. Karakteristik fisikokimia yang diuji meliputi: rendemen, warna, ukuran partikel, analisis proksimat (kadar air, abu, protein dan lemak), kadar kalsium dan fosfor, uji morfologi, analisis senyawa penyusun dan sifat kritalinitas bahan.

\section{BAHAN DAN METODE}

\section{Bahan}

Bahan yang digunakan adalah limbah tulang ikan nila yang diperoleh dari PT. Aqua Farm, Semarang.

\section{Metode penelitian}

Penelitian ini dibagi menjadi tiga tahapan proses yaitu: (1) Persiapan bahan baku; (2) Ekstraksi nanokalsium tulang ikan dan (3) Karakterisasi sifat fisikokimia sampel bahan baku (BB) dan nanokalsium (NKEB dan NKEA) seperti pada Gambar 1.

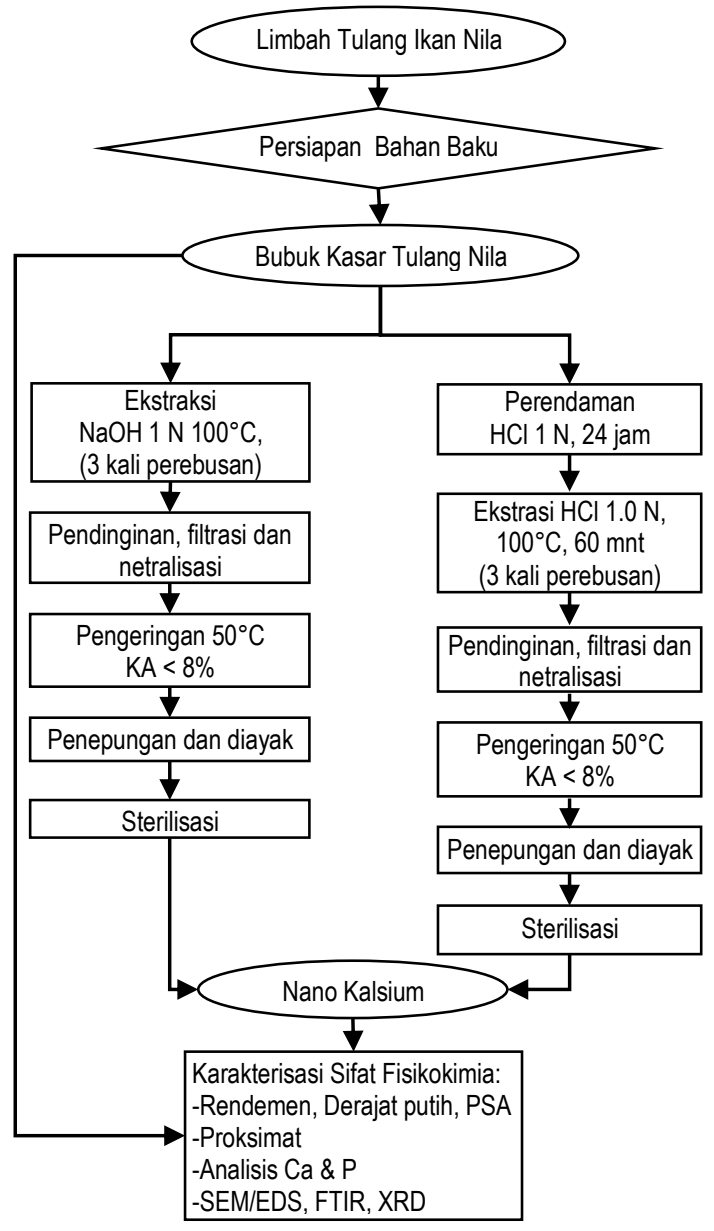

Gambar 1. Diagram alir tahapan penelitian

Tahap pertama yaitu persiapan bahan baku (bubuk tulang ikan nila), yang bertujuan untuk menghasilkan bahan baku tulang ikan nila yang siap diekstraksi melalui beberapa tahapan proses seperti pencucian, perebusan, pengeringan dan pengecilan ukuran menggunakan hammer mill.

Tahapan kedua yaitu ekstraksi tulang ikan nila menggunakan 2 pelarut yang berbeda yaitu larutan basa $(\mathrm{NaOH})$ dan asam $(\mathrm{HCl})$ secara terpisah, yang bertujuan untuk melunakkan tulang ikan nila sehingga memudahkan dalam proses penepungan.

\section{Ekstraksi dengan larutan basa $(\mathrm{NaOH})$}

Bubuk kasar tulang ikan nila diekstraksi dengan larutan $\mathrm{NaOH}$ (Merck) $1 \mathrm{~N}$ (sampel:pelarut $=1: 3$ ) pada suhu $100^{\circ} \mathrm{C}$ selama 60 menit. Proses ekstraksi ini dilakukan sebanyak 3 kali. Hasil ekstraksi selanjutnya didinginkan, difiltrasi, dinetralisasi hingga mencapai $\mathrm{pH}$ netral dan dikeringkan menggunakan oven pada suhu $50^{\circ} \mathrm{C}$ hingga mencapai kadar air $<8 \%$. 


\section{Ekstraksi dengan larutan asam $(\mathrm{HCl})$}

Bubuk kasar tulang ikan nila dihidrolisis menggunakan $\mathrm{HCl}$ (Merck) $1 \mathrm{~N}$ (sampel:pelarut = 1:3) selama 24 jam pada suhu ruang, selanjutnya diekstraksi pada suhu $100^{\circ} \mathrm{C}$ selama 60 menit. Proses ekstraksi ini dilakukan sebanyak 3 kali dan hasil ekstraksi kemudian didinginkan, difiltrasi dan dinetralkan menggunakan akuades hingga sampel pH netral, setelah itu dikeringkan menggunakan oven pada suhu $50^{\circ} \mathrm{C}$ hingga mencapai kadar air $<8 \%$.

Bubuk tulang ikan nila yang telah diekstraksi menggunakan $\mathrm{NaOH}$ dan $\mathrm{HCl}$ selanjutnya dijadikan tepung menggunakan disc mill kemudian diayak menggunakan pengayak berukuran 100 mesh. Proses sterilisasi dilakukan pada suhu $121^{\circ} \mathrm{C}$ selama 15 menit untuk mempertahankan mutu dan memperpajang umur simpan tepung tulang yang dihasilkan, seperti pada Gambar 1.

\section{Karakterisasi sifat fisikokimia sampel bahan baku dan nanokalsium}

Pengujian yang dilakukan meliputi penentuan rendeman, warna diukur menggunakan spectrophotometer (Hunterlab Color Flex EZ spectrophotometers (Lab Color Solid)) dan ukuran partikel menggunakan Particle Size Analyzer (PSA) merek Vasco-PSA, reflactometer Arago DL 135, Cordouan. Sampel diukur menggunakan metode LALLS (Low Angle Laser Light Scattering) dapat digunakan untuk ukuran partikel 0.1$3000 \mu \mathrm{m}$ dengan sinar laser pada intensitas gas $\mathrm{He}-\mathrm{Ne}$ $(\lambda=0.63 \mu \mathrm{m})$. Analisis proksimat meliputi kadar air (AOAC, 925.09, 2005), abu (AOAC, 941.12, 2005), protein kasar (AOAC, 920.87, 2005) dan lemak (AOAC, 960.39, 2005). Analisis kalsium menggunakan Atomic Absorption Spectrometry (AAS) (Perkin Elmer Analyst 100 type flame) dengan metode pengabuan basah pada $\lambda=422.7 \mathrm{~nm}$ (AOAC, 968.08, 2005) dan fosfor (spektro-fotometer UV-vis) pada $\lambda=660 \mathrm{~nm}$ (AOAC, $948.09,2005)$. Analisis morfologi pada sampel yang dilapisi dengan emas-palladium $(60: 40)$ setebal $48 \mathrm{~nm}$, selanjutnya diamati menggunakan SEM (JEOL, JSM-35C) pada tegangan 22 kV. (Toya et al. 1986). Analisis senyawa penyusun dilakukan pada sampel yang dihomogenisasi dengan $\mathrm{KBr}$, dan dibentuk pellet kepingan tipis, selanjutnya diukur spektrumnya menggunakan FTIR (Spectrum one-FT-IR Spectrometer C69526, Perkins Eimer Precisely pada area IR $\left(4000-400 \mathrm{~cm}^{-1}\right)$, dengan kecepatan 32 detik dan resolusi $4 \mathrm{~cm}^{-1}$. (Huang et al. 2011). Sifat kristalinitas sampel diukur menggunakan $X$-ray Diffraction (XRD) merek Emma GBC kisaran $2 \theta$ pada suhu $10^{\circ}$ sampai $80^{\circ}$ dan ukuran langkah $0.1^{\circ}$ pada $\mathrm{Cu}$ dengan panjang gelombang $1.5406 \AA$ (Huang et al. 2011).

\section{HASIL DAN PEMBAHASAN}

\section{Karakteristik fisikokimia}

Rendemen adalah parameter penting untuk mengetahui nilai ekonomis dan efektivitas suatu produk atau bahan. Rendemen tulang ikan nila bersih setelah dipisahkan dari sisa daging, lendir dan darah yang menempel pada tulang dan dikeringkan adalah $9.45 \%$ (bk), setelah dilakukan pengecilan ukuran menggunakan hammer mill menjadi bubuk tulang kasar atau sampel BB $(0.2-0.5 \mathrm{~cm})$ adalah $7.39 \%$ (bk). Rendemen NKEB (nanokalsium ekstraksi basa) adalah $5.91 \%$ (bk) dan NKEA (nanokalsium ekstraksi asam) adalah $4.41 \%$ (bk). Berdasarkan hasil rendemen menunjukkan bahwa ekstraksi menggunakan basa memiliki hasil yang lebih tinggi dibandingkan dengan ekstraksi menggunakan asam. Hasil analisis rendemen, warna, ukuran partikel dan proksimat, serta kalsium dan fosfor sampel BB, NKEB dan NKEA seperti terlihat pada Tabel 1.

Tabel 1. Sifat fisikokimia BB, NKEB, NKEA dan TPB

\begin{tabular}{|c|c|c|c|c|}
\hline Parameter & $\mathrm{BB}$ & NKEB & NKEA & TBP \\
\hline Rendemen (\%) & 7.39 & 5.91 & 4.41 & - \\
\hline$L^{*}$ & $\begin{array}{c}88.34 \pm \\
0.69\end{array}$ & $\begin{array}{c}94.78 \pm \\
2.57\end{array}$ & $\begin{array}{c}93.14 \pm \\
0.16\end{array}$ & $\begin{array}{c}98.08 \pm \\
0.04\end{array}$ \\
\hline Warna & $\begin{array}{c}-0.86 \pm \\
0.01\end{array}$ & $\begin{array}{c}0.21 \pm \\
0.68\end{array}$ & $\begin{array}{c}0.49 \pm \\
0.04\end{array}$ & $\begin{array}{c}16.79 \pm \\
0.06\end{array}$ \\
\hline$b^{*}$ & $\begin{array}{c}10.15 \pm \\
0.02\end{array}$ & $\begin{array}{c}6.57 \pm \\
1.75\end{array}$ & $\begin{array}{c}11.00 \pm \\
0.22\end{array}$ & $\begin{array}{c}79.48 \pm \\
0.09\end{array}$ \\
\hline Ukuran Partikel (nm) & 655.69 & 235.93 & 242.35 & - \\
\hline Air (\%) & $\begin{array}{c}8.76 \pm \\
0.26\end{array}$ & $\begin{array}{c}4.67 \pm \\
0.05\end{array}$ & $\begin{array}{c}4.34 \pm \\
0.56\end{array}$ & $\begin{array}{c}2.46 \pm \\
0.03\end{array}$ \\
\hline Abu (\%) & $\begin{array}{c}69.37 \pm \\
0.03\end{array}$ & $\begin{array}{c}95.93 \pm \\
0.14\end{array}$ & $\begin{array}{c}85.44 \pm \\
0.41\end{array}$ & $\begin{array}{c}75.83 \pm \\
0.12\end{array}$ \\
\hline Protein (\%) & $\begin{array}{c}26.06 \pm \\
0.31\end{array}$ & $\begin{array}{c}0.38 \pm \\
0.13\end{array}$ & $\begin{array}{c}7.03 \pm \\
0.17\end{array}$ & $\begin{array}{c}14.81 \pm \\
0.33\end{array}$ \\
\hline Lemak (\%) & $\begin{array}{c}2.85 \pm \\
0.09\end{array}$ & $\begin{array}{c}0.94 \pm \\
0.11\end{array}$ & $\begin{array}{l}1.79 \pm \\
0.24\end{array}$ & $\begin{array}{c}5.82 \pm \\
0.04\end{array}$ \\
\hline Kalsium (\%) & $\begin{array}{c}18.70 \pm \\
0.140\end{array}$ & $\begin{array}{c}20.67 \pm \\
0.340\end{array}$ & $\begin{array}{c}21.48 \pm \\
0.030\end{array}$ & - \\
\hline Fosfor (\%) & $\begin{array}{l}8.91 \pm \\
0.039\end{array}$ & $\begin{array}{c}10.09 \pm \\
0.546\end{array}$ & $\begin{array}{c}11.78 \pm \\
0.448\end{array}$ & - \\
\hline
\end{tabular}

Keterangan: Bahan baku (BB); NKEB (NaOH); NKEA (HCl); Tilapia Bone Powder (TPB) Hemung (2013)

Hasil analisis warna pada penelitian ini (Tabel 1) lebih rendah dibandingkan warna tepung tulang ikan nila pada penelitan Hemung (2013) dengan nilai $L^{*}, a^{*}$ dan $b^{*}$ adalah 98.08; 16.79; dan 79.48. Namun lebih tinggi dibandingkan kalsium tulang ikan nila pada penelitian Techochatchawal et al. (2009) dengan nilai $L^{*}, a^{*}$ dan $b^{*}$ adalah $73.57 ; 0.88$; dan 18.44 . Warna tepung yang dihasilkan berkaitan dengan kandungan senyawa organik yang terdapat dalam tepung (Hemung, 2013). Warna alami tulang ikan adalah kuning cerah (Venkatesan dan Kim, 2010), sementara warna sampel NKEB dan NKEA berwarna putih cerah. Perbandingan warna NKEB lebih putih dan cerah dibandingkan sampel NKEA, hal ini menunjukkan bahwa ekstraksi menggunakan larutan basa menghasilkan warna tepung yang lebih baik dibandingkan menggunakan larutan asam. Ekstraksi dengan larutan asam mengakibatkan terbentuk warna kehitaman atau melamin akibat adanya kandungan indol triptopan dengan aldehid yang berasal dari karbohidrat yang terdapat pada bahan (Venkatesan dan Kim, 2010). Hasil ini juga ditunjukkan dalam bentuk kalsinasi sampel NKEA pada suhu $550^{\circ} \mathrm{C}$ menghasilkan bubuk yang berwarna hitam dan NKEB berwarna putih, sementara sampel BB berwarna kuning cerah.

Rata-rata hasil pengukuran partikel sampel BB $(655.69 \mathrm{~nm})$, NKEB $(235.93 \mathrm{~nm})$ dan NKEA $(242.35 \mathrm{~nm})$ seperti pada Tabel 1 dengan intensitas ukuran terdispersi seperti pada Gambar 2. Berdasarkan nilai ukuran partikel menunjukkan bahwa partikel sampel NKEA relatif lebih besar dibandingkan NKEB. Ukuran partikel sampel pada penelitain dapat digolongkan ke dalam nanopartikel seperti yang dijelaskan oleh Mohanraj dan Chen 
(2006) nanopartikel adalah partikel yang berukuran 10-1000 $\mathrm{nm}$. Menurut Greiner (2009), nanopartikel umumnya digunakan ketika mengacu pada bahan-bahan dengan ukuran 1-100 nm. Ukuran partikel nanokalsium yang dihasilkan tidak berbeda dengan ukuran nanopartikel yang dihasilkan oleh Khoerunnisa (2011) yaitu 120-573 nm dengan SEM pada pembesaran 20.000x. Ukuran partikel dan ukuran distribusi merupakan karakteristik terpenting dalam sistem nanopartikel karena berpengaruh dalam penentuan distribusi parikel secara in vivo, kondisi biologis, toksisitas dan kemampuan target dari sistemnya, serta mempengaruhi sistem kelarutan dan stabilitasnya (Mohanraj dan Chen, 2006).
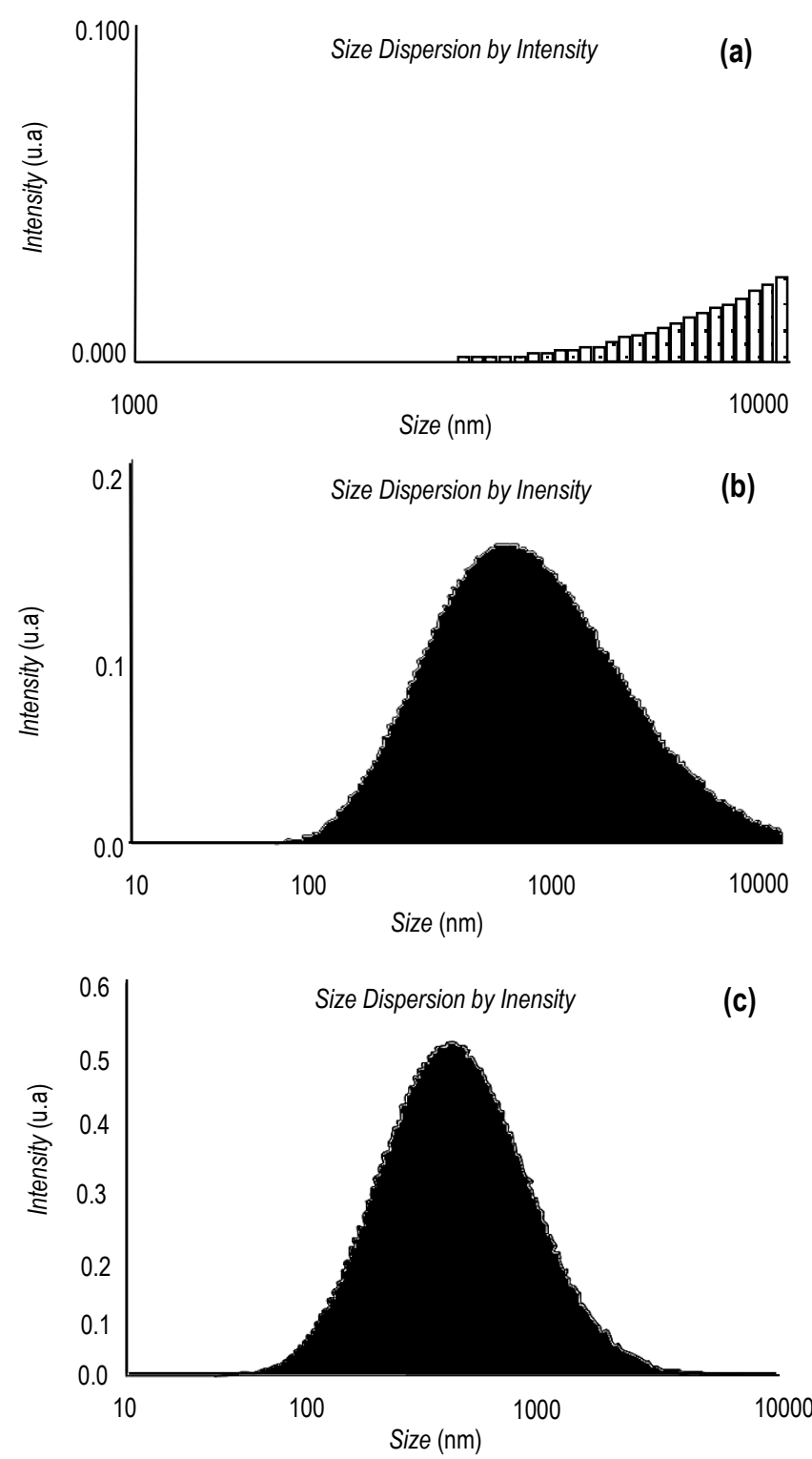

Gambar 2. Ukuran partikel sampel (a) bahan baku (BB), (b) nanokalsium ekstraksi basa (NKEB) dan (c) nanokalsium ekstraksi asam (NKEA)

Hasil analisis proksimat sampel pada penelitian seperti disajikan pada Tabel 1. Kadar abu sampel BB $(69.37 \%$ bk), NKEB $(95.93 \%$ bk) lebih tinggi dibandingkan NKEA $(85.44 \%$ bk). Kadar abu penelitian ini lebih tinggi dibandingkan kadar abu tulang ikan salmon, kakap dan lele yang dihidrolisis menggunakan $\mathrm{NaOH} 3 \%$ yaitu 21-24.4\% (Luu dan Nguyen, 2009) serta kadar abu Tilapia Bone Powder (TBP) pada penelitian Hemung (2013) yaitu $75.83 \%$ (bk).

Kadar protein sampel BB $(26.06 \%$ bk) lebih rendah dibandingkan kadar protein tepung tulang ikan nila tilapia pada penelitian Vignesh dan Srinivasa (2012) yaitu $31.52 \%$. Kadar protein sampel NKEB $(0.38 \%$ bk) dan NKEA $(7.03 \%$ bk), lebih rendah dibandingkan kadar protein TBP pada penelitian Hemung (2013) yaitu 14.81\% (bk). Hasil ini menunjukkan bahwa ekstraksi menggunakan $\mathrm{NaOH} 1 \mathrm{~N}$ dapat menurunkan kadar protein tulang ikan sebesar $98 \%$ sedangkan ekstraksi menggunakan $\mathrm{HCl} 1 \mathrm{~N}$ hanya $71 \%$, sehingga disimpulkan bahwa hidrolisis protein pada tulang ikan menggunakan larutan basa lebih efektif dibandingkan larutan asam.

\section{Kadar kalsium dan fosfor}

Kadar kalsium sampel BB (18.70\%), NKEB $(20.67 \%)$ dan NKEA $(21.48 \%)$, sedangkan kadar fosfor sampel BB $(8.91 \%)$, NKEB $(10.09 \%)$ dan NKEA $(11.78 \%)$ dengan rasio perbandingan $\mathrm{Ca} / \mathrm{P}$ secara berturut adalah 2.09; 2.05; dan 1.82. Perubahan rasio perbandingan $\mathrm{Ca} / \mathrm{P}$ pada sampel NKEB dan NKEA, disebabkan karena perlakuan ekstraksi menggunakan asam dan basa mengakibatkan terhidrolisisnya protein dan lemak yang terdapat pada matriks tulang (sampel BB), sehingga meningkatkan kadar kalsium dan fosfor pada sampel. Kadar kalsium dan fosfor pada penelitian ini relatif lebih rendah dibandingkan kadar kalsium dan fosfor tulang ikan nila tilapia pada penelitian Petenuci et al. (2008) yaitu 27.15 dan $11.33 \%$, serta tepung tulang ikan salmon, kakap dan lele yaitu 21.023.3\% dan 10.5-11.0\% (Luu dan Nguyen, 2009).

\section{Spektra Fourier Transform Infrared (FTIR)}

Spektra FTIR menunjukkan terbentuk gugus fosfat $\left(\mathrm{PO}_{4}{ }^{3-}\right)$, apatit karbonat $\left(\mathrm{CO}_{3}{ }^{2}\right)$ dan hidroksil $(\mathrm{OH}-)$ pada semua sampel yang dianalisi seperti disajikan pada Tabel 2. Apatit karbonat adalah komponen anorganik dalam tulang dan gigi, berdasarkan lokasinya subtitusi $\mathrm{CO}_{3}^{2-}$ terdiri dari 2 tipe yaitu apatit karbonat tipe $\mathrm{A}(\mathrm{AKA})$ terbentuk jika ion karbonat menggantikan posisi $\mathrm{OH}^{-}$dan apatit karbonat tipe $\mathrm{B}(\mathrm{AKB})$ jika karbonat menggantikan posisi ion $\mathrm{PO}_{4}{ }^{3-}$ (Mathai dan Takagi, 2001).

Tabel 2. Hasil spektra FTIR bahan baku, NKEB dan NKEA

\begin{tabular}{|c|c|c|c|c|c|c|}
\hline \multirow{2}{*}{ Senyawa } & \multicolumn{2}{|c|}{$\mathrm{BB}$} & \multicolumn{2}{|c|}{ NKEB } & \multicolumn{2}{|c|}{ NKEA } \\
\hline & $\mathrm{cm}^{-1}$ & $\% \mathrm{~T}$ & $\mathrm{~cm}^{-1}$ & $\% \mathrm{~T}$ & $\mathrm{~cm}^{-1}$ & $\% \mathrm{~T}$ \\
\hline$v_{1} \mathrm{PO}_{4}$ & \multirow{2}{*}{\multicolumn{2}{|c|}{ - }} & 962 & 25.4 & 959 & 33.9 \\
\hline$v_{2} \mathrm{PO}_{4}$ & & & 469 & 43.13 & 474 & 50.29 \\
\hline \multirow{3}{*}{$\begin{array}{l}v_{3} \mathrm{PO}_{4} \\
v_{4} \mathrm{PO}_{4}\end{array}$} & 1035 & 12.63 & 1035 & 0 & 1031 & 6.67 \\
\hline & 563 & 25.08 & 564 & 2.94 & 562 & 18.75 \\
\hline & 602 & 28.66 & 603 & 4.72 & 603 & 24.5 \\
\hline AKA & & & 1547 & 41.73 & 1563 & 50.48 \\
\hline \multirow[t]{3}{*}{ AKB } & 872 & 47.09 & 873 & 41.1 & 873 & 46.64 \\
\hline & 1417 & 37.9 & 1416 & 19.35 & 1415 & 47.3 \\
\hline & 1455 & 38.06 & 1455 & 19.06 & 1456 & 46.66 \\
\hline \multirow[t]{2}{*}{$\mathrm{OH}$} & 1648 & 40.79 & 1634 & 42.06 & 1647; & 43.79 \\
\hline & 3429 & 36.55 & 3435 & 13.97 & 3430 & 38.24 \\
\hline OH Kristal & 3698 & 59.83 & \multicolumn{2}{|r|}{70.} & \multicolumn{2}{|l|}{ 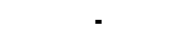 } \\
\hline
\end{tabular}

Keterangan: Bahan baku (BB); nanokalsium ekstraksi basa (NKEB); nanokalsium ekstraksi asam (NKEA); Sumber refensi: Dahlan et al. (2006); Huang et al. (2011); Karthikeyan (2011) 
Spektra FTIR yang terbentuk pada sampel BB, NKEB dan NKEA seperti terlihat pada Gambar 3 dalam jangkauan bilangan gelombang $400-4000 \mathrm{~cm}^{-1}$. Pita absorpsi fosfat fosfat $v_{1}$ (vibrasi simetris strectching) dan $v_{2}$ (vibrasi simetris bending) pada spektra sampel NKEB berada di daerah $962 \mathrm{~cm}^{-1}$ dan $469 \mathrm{~cm}^{-1}$, sedangkan sampel NKEA berada pada pita absorpsi $959 \mathrm{~cm}^{-1}$ dan $474 \mathrm{~cm}^{-1}$, sementara kedua pita absorpsi fosfat $v_{1}$ dan fosfat $v_{2}$ tidak tampak pada spektra sampel BB.

Pita absorpsi fosfat $v_{3}$ (vibrasi asimetris strectching) pada spektra sampel BB dan NKEB terdapat bilangan gelombang $1035 \mathrm{~cm}^{-1}$, sementara NKEA terbentuk disekitar $1031 \mathrm{~cm}^{-1}$. Pita absorpsi fosfat $v_{4}$ (vibrasi asimetris bending) ditandai dengan pita absorpsi dalam bentuk belah di daerah 563 dan $603 \mathrm{~cm}^{-1}$ pada semua spektra sampel, yang menunjukkan akan kehadiran kristal hidroksiapatit (HAP). Derajat belah pita absorpsi fosfat $v_{4}$ (vibrasi asimetris bending) selain mengindikasi adanya kristal apatit tapi juga menunjukkan kandungan fasa kristal dalam sampel (Dahlan et al. 2006).

Pita absorpsi gugus apatit karbonat tipe B (AKB) terindentifikasi pada sampel BB, NKEB dan NKEA di daerah sekitar 873,1416 dan $1455 \mathrm{~cm}^{-1}$, pita absorpsi $1547 \mathrm{~cm}^{-1}$ pada sampel NKEB dan $1563 \mathrm{~cm}^{-1}$ pada NKEA mencirikan apatit karbonat tipe $A(A K A)$, sementara pada spektra sampel BB pita absorpsi AKA tidak tampak.

Spektra yang menunjukkan adanya kehadiran air permukaan terbentuk pada semua sampel pada pita absorpsi lebar gugus hidroksil di daerah $3429-3435 \mathrm{~cm}^{-1}$ dan pita absorpsi kecil di daerah 1634-1656 $\mathrm{cm}^{-1}$, sedangkan indikasi air kristal hanya terdapat pada spektra sampel BB di daerah $3698 \mathrm{~cm}^{-1}$.

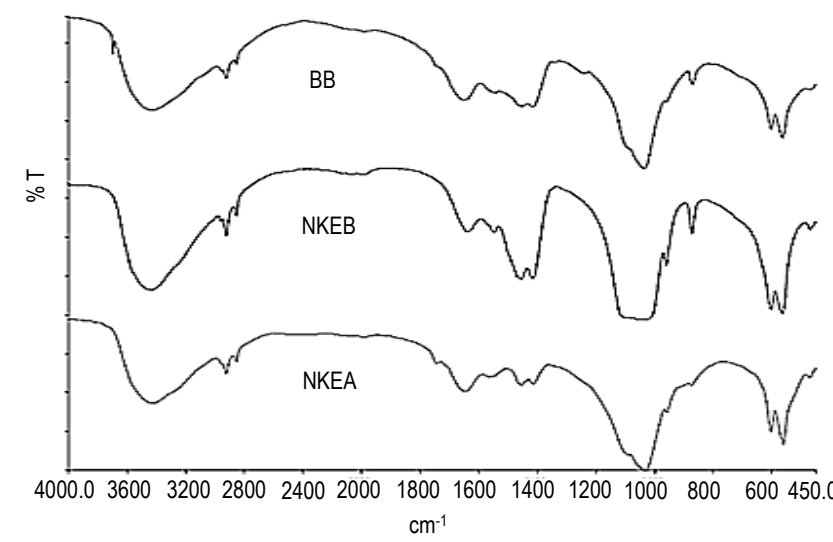

Gambar 3. Spektrum FTIR sampel bahan baku (BB), nanokalsium ekstraksi basa (NKEB) dan nanokalsium ekstraksi asam (NKEA)

Pita absorpsi spektra FTIR pada penelitian ini memiliki kemiripan dengan hasil penelitian Huang et al. (2011) dimana karakteristik spektra bubuk FHAP (fish hidroxyapatite) menunjukkan gugus fosfat $\left(\mathrm{PO}_{4}^{3-}\right)$ terdapat di daerah 563,957 dan $1030 \mathrm{~cm}^{-1}$, sementara gugus apatit karbonat $\left(\mathrm{CO}_{3}{ }^{2-}\right)$ terindikasi pada 876 dan $1412-1547 \mathrm{~cm}^{-1}$.

Kristalinitas kalsium fosfat ditunjukkan oleh pita absorpsi fosfat $v_{3}$ sampel BB dan NKEB terlihat di daerah $1035 \mathrm{~cm}^{-1}$ sedangkan untuk NKEA terbentuk di daerah $1031 \mathrm{~cm}^{-1}$ hal ini menunjukkan bahwa kalsium fosfat pada tulang nila hadir dalam bentuk campuran fasa amorfus dan fasa kristalin. Hasil yang sama pada tulang tikus di daerah pita absorpsi $1036 \mathrm{~cm}^{-1}$ menunjukkan adanya campuran fasa amorfus dan fasa kristalin (Dahlan et al. 2006), selanjutnya dijelaskan pula bahwa bentuk pita $v_{3}$ fosfat dan $v_{4}$ fosfat adalah pita asimetris yang mengindikasikan bahwa senyawa sampel tidak seluruhnya dalam bentuk amorf.

\section{Morfologi Scanning Electron Microscopy (SEM)}

Analisis morfologi menggunakan SEM semua sampel seperti pada Gambar 4, menunjukkan morfologi permukaan sampel BB memiliki ukuran butiran kalsium yang relatif besar dengan bentuk tidak beraturan, halus, datar dan padat. Morfologi permukaan sampel NKEB terlihat lebih halus, padat dan berbentuk bongkahan akibat gabungan beberapa butiran kalsium. Ukuran butiran sampel NKEB yang terbentuk relatif lebih besar dibandingkan dengan butiran NKEA. Sampel NKEA memiliki struktur permukaan lebih kasar, tajam dan berpori dengan butiran yang relatif kecil dan tidak beraturan.

Hasil ini didukung dengan hasil analisis menggunakan XRD, yang menunjukkan derajat kristalinitas dan ukuran kristal sampel NKEB lebih besar dibandingkan sampel NKEA (Tabel 4), sehingga mengakibatkan terjadinya perbedaan morfologi permukaan sampel akibat perlakuan yang diberikan. Sampel hasil ekstraksi menggunakan asam memiliki ukuran kristal yang lebih kecil dan derajat kristalinitas yang lebih rendah akibatnya morfologi permukaan sampel yang dihasilkan lebih berpori dan tajam, sementara hasil ekstraksi menggunakan basa menunjukkan hasil yang sebaliknya.

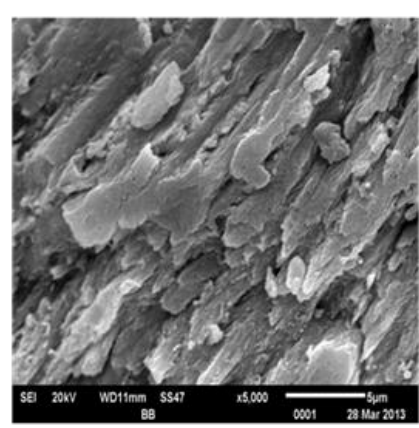

(a)

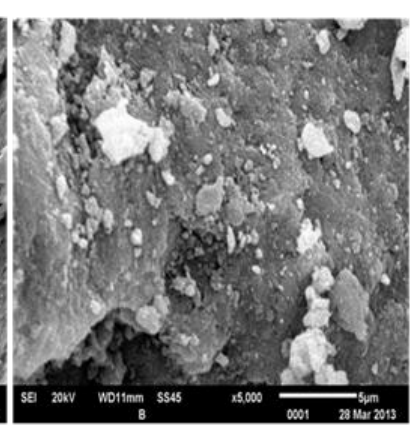

(b)

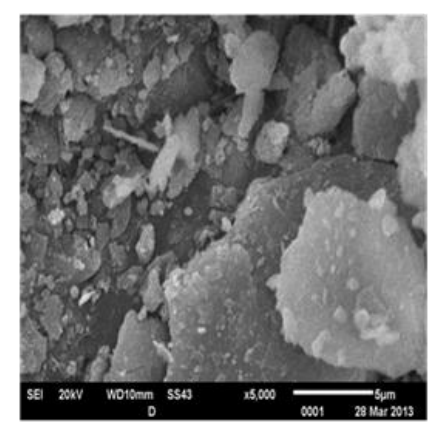

(c)

Gambar 4. Morfologi SEM sampel (a) sampel bahan baku (BB), (b) nanokalsium ekstraksi basa (NKEB) dan (c) nanokalsium ekstraksi asam (NKEA) pembesaran $5.000 \mathrm{x}$ 


\section{$X$-ray Diffraction (XRD)}

Analisis menggunakan XRD dilakukan untuk mengetahui fasa yang terbentuk, derajat kristalinitas, dan ukuran kristal sampel yang dilakukan dengan mencocokkan data JCPDS (Joint Committee on Powder Diffraction Standards). Hasil analisis XRD untuk sampel BB, NKEB dan NKEA, seperti yang disajikan pada Tabel 3.

Senyawa yang terbentuk dalam sampel adalah kalsium fosfat dengan rumus kimia $\mathrm{Ca}_{4} \mathrm{P}_{2} \mathrm{O}_{9}$, dalam bentuk kristalin dan amorf. Fasa kristalin yang terbentuk dan mendominasi sampel $\mathrm{BB}$ adalah apatit karbonat atau $\left[\mathrm{Ca}_{10}\left(\mathrm{PO}_{4}\right)_{3}\left(\mathrm{CO}_{3}\right)_{3}(\mathrm{OH})_{2}\right]$. Fasa kristalin pada sampel NKEB dan NKEA adalah apatit karbonat dan hidroksiapatit $\left[\mathrm{Ca}_{5}\left(\mathrm{PO}_{4}\right)_{3}(\mathrm{OH})\right]$. Kehadiran fasa amorf pada tulang menunjukkan bahwa pembentukan kristal stabil apatit didahului oleh pembentukan kristal non apatit.

Apatit karbonat pada sampel $\mathrm{BB}$ merupakan bentuk apatit karbonat tipe $B(A K B)$ atau $\left[\mathrm{Ca}_{10}\left(\mathrm{PO}_{4}\right)_{3}\left(\mathrm{CO}_{3}\right)_{3}(\mathrm{OH})_{2}\right]$ yang terbentuk pada sudut 25.92, 31.84, 40.1, 46.82 dan $49.47^{\circ}$, sedangkan pada sampel NKEB terbentuk pada sudut $2 \theta=28.6$ dan $46.74^{\circ}$, sementara untuk sampel NKEB terbentuk pada sudut $2 \theta=25.96,28.6,46.4$ dan $49.36^{\circ}$. Apatit karbonat tipe $A$ (AKA) atau $\left[\mathrm{Ca}_{10}\left(\mathrm{PO}_{4}\right)_{6} \mathrm{CO}_{3}\right]$ tidak terlihat pada sampel $\mathrm{BB}$, sedangkan pada sampel NKEB terbentuk pada sudut $2 \theta=25.9$ dan $53.18^{\circ}$, dan sampel NKEA terlihat pada sudut $2 \theta=33.9$, 39.68 dan $53.28^{\circ}$. Fasa kristalin pada sampel NKEB dan NKEA selain apatit karbonat juga terbentuk fasa HAp (hidroksiapatit). Fasa HAp sampel NKEB terbentuk pada sudut $2 \theta=31.86,40.1$ dan $49.64^{\circ}$, sedangkan sampel $D$ terbentuk pada sudut $2 \theta=$ 30.2 dan $31.6^{\circ}$.

Tabel 3. Puncak-puncak profil XRD sampel BB, NKEB dan NKEA

\begin{tabular}{cccc}
\hline \multirow{2}{*}{ Fasa } & BB & NKEB & NKEA \\
\cline { 2 - 4 } & $2 \theta\left(^{\circ}\right)$ & $2 \theta\left(^{\circ}\right)$ & $2 \theta\left(^{\circ}\right)$ \\
\hline AKA & - & 25.9 & 33.9 \\
& - & 53.18 & 39.68 \\
& - & - & 53.28 \\
\hline AKB & 25.92 & 28.6 & 25.96 \\
& 31.84 & 46.74 & 28.6 \\
& 40.1 & - & 46.4 \\
& 46.82 & - & 49.36 \\
& 49.47 & - & - \\
\hline HAp & - & 31.86 & 30.2 \\
& - & 40.1 & 31.6 \\
& - & 49.64 & - \\
\hline
\end{tabular}

Keterangan: Bahan baku (BB); nanokalsium ekstraksi basa (NKEB) nanokalsium ekstraksi asam (NKEA); apatit karbonat tipe A (AKA); apatit karbonat tipe B (AKB); hidroksiapatit (HAp)

Hasil pengukuran derajat kristalinitas sampel (Tabel 4), menunjukkan sampel NKEB lebih kristalin dibanding sampel nanokalsium lainnya. Tulang ikan nila secara alami memiliki derajat kristalinitas yang lebih rendah (sampel BB) dibandingkan dengan sampel hasil ekstraksi menggunakan asam dan basa, hal ini diduga berhubungan dengan hilangnya sejumlah senyawa organik selama proses ekstraksi. Derajat kristalinitas sampel secara berturut-turut adalah sampel BB (71.4\%), NKEB (78.4\%) dan NKEA (73.5\%). Proses isolasi hidroksiapatit (HAp) dari tulang ikan tuna menggunakan suhu tinggi mengakibatkan hilangnya senyawa organik sehingga meningkatkan kemurnian, stabilitas dan kristalinitas HAp yang terbentuk (Venkatesan dan Kim, 2010). Ukuran kristal, seperti terlihat pada Tabel 4 merupakan hasil perhitungan menggunakan persamaan Scherrer yaitu:

$$
D=\frac{k \cdot \lambda}{B \cdot \operatorname{Cos}\left(\theta_{\beta}\right)}
$$

Dari rumus tersebut diketahui bahwa $\mathrm{k}$ adalah konstanta yang nilainya bervariasi, untuk tulang nilainya adalah $0.9, \lambda$ adalah panjang gelombang sinar- $X$ yang digunakan yaitu $1.540958(\AA)$, merupakan panjang gelombang $\mathrm{Cu}$ sebagai sumber sinar-X, $\theta_{\beta}$ adalah sudut Bragg, $B$ adalah FWHM (full with half maximum) yang dipilih. Harga FWHM berbanding terbalik dengan ukuran kristal, makin kecil harga FWHM maka ukuran kristal yang dihasilkan semakin besar.

Tabel 4. Derajat kristalinitas dan ukuran kristal sampel

\begin{tabular}{ccccccc}
\hline Sampel & $\begin{array}{c}\text { Kristalinitas } \\
(\%)\end{array}$ & $2 \theta\left(^{\circ}\right)$ & $\begin{array}{c}\text { FWHM } \\
\beta\left(^{\circ}\right)\end{array}$ & $\begin{array}{c}\beta \\
\left({ }^{\circ}\right)\end{array}$ & $\begin{array}{c}\beta \\
(\mathrm{rad})\end{array}$ & $\begin{array}{c}\mathrm{D}_{(002)} \\
(\mathrm{nm})\end{array}$ \\
\hline BB & 71.4 & 25.92 & 0.504 & 0.252 & 0.0044 & 283.68 \\
NKEB & 78.4 & 25.9 & 0.332 & 0.166 & 0.0029 & 430.69 \\
NKEA & 73.5 & 25.96 & 0.894 & 0.447 & 0.0078 & 159.87 \\
\hline
\end{tabular}

Ukuran kristal pada sudut $2 \theta=25.8-25.96$ seperti pada Tabel 4, menunjukkan sampel NKEB memiliki ukuran kristal lebih besar dibandingkan dengan sampel lainnya, sedangkan ukuran kristal terkecil terbentuk pada sampel NKEA. Hasil ini menunjukkan bahwa ekstraksi menggunakan asam menghasilkan ukuran kristal lebih kecil dibandingkan penggunaan larutan basa. Puncak maksimum intensitas fasa (Gambar 5) pada sampel BB terbentuk pada sudut $2 \theta=31.84^{\circ}$ dan sampel NKEB pada sudut $2 \theta=31.86^{\circ}$ sedangkan NKEA pada sudut $2 \theta$ $=31 \cdot 6^{\circ}$. Berdasarkan hasil ini dapat disimpulkan bahwa metode ekstraksi yang digunakan tidak mempengaruhi sudut dengan intensitas maksimum kalsium pada sampel, akan tetapi jenis pelarut untuk ekstraksi mempengaruhi perubahan fasa yang terbentuk pada puncak tertinggi. Pada sampel BB puncak tertinggi merupakan apatit karbonat tipe $\mathrm{B}\left[\mathrm{Ca}_{10}\left(\mathrm{PO}_{4}\right)_{3}\left(\mathrm{CO}_{3}\right)_{3}\right.$ $(\mathrm{OH})_{2}$ ], sedangkan pada sampel NKEB dan NKEA merupakan fasa kalsium hidroksiapatit $\left[\mathrm{Ca}_{5}\left(\mathrm{PO}_{4}\right)_{3}(\mathrm{OH})\right]$.

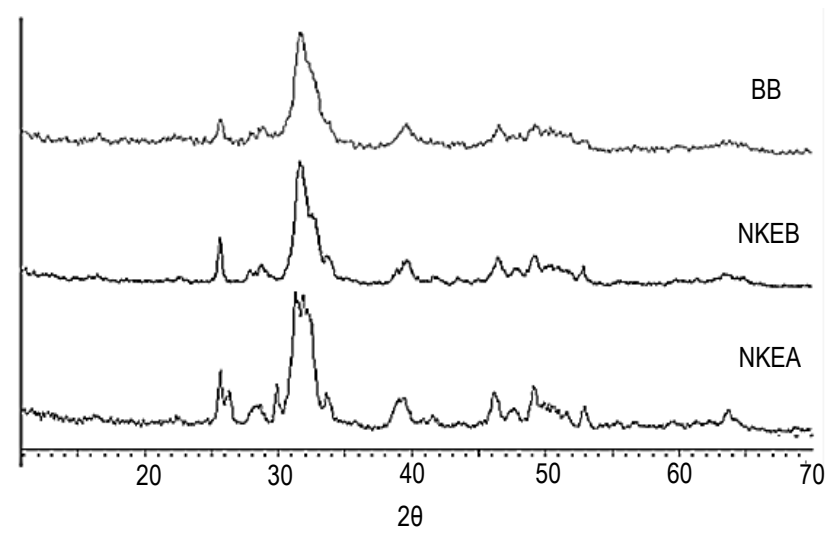

Gambar 5. Grafik XRD sampel bahan baku (BB), nanokalsium ekstraksi basa (NKEB) dan nanokalsium ekstraksi asam (NKEA) 
Deklinasi spektrum pada $2 \theta$ sudut 20 hingga $25^{\circ}$ menunjukkan adanya amorfus sedangkan puncak pada $2 \theta$ sudut 30 hingga $35^{\circ}$ menunjukkan bahwa kristal mineral sampel NKEB dan NKEA memiliki partikel berukuran kecil dalam skala nano. Hasil yang sama ditunjukkan pada difraksi sinar-x tulang tikus (Dahlan et al. 2006).

Hasil analisis FTIR menunjukkan gugus fungsi terbentuk pada sampel adalah gugus fosfat $\left(\mathrm{PO}_{4}^{3-}\right)$, karbonat $\left(\mathrm{CO}_{3}{ }^{2}\right)$ dan hidroksil $(\mathrm{OH}-)$ dalam fasa amorf dan kristalin, yang ditandai dengan $v_{4}$ fosfat dalam bentuk pita belah pada bilangan gelombang 563 dan $603 \mathrm{~cm}^{-1}$. Hasil ini didukung oleh data analisis menggunakan XRD yang menunjukkan adanya fasa amorf dan kristalin pada semua sampel, yang didominasi oleh fasa apatit karbonat pada sampel BB, sedangkan sampel NKEB dan NKEA selain apatit karbonat, terbentuk juga hidroksiapatit $\left[\mathrm{Ca}_{5}\left(\mathrm{PO}_{4}\right)_{3}(\mathrm{OH})\right]$. Analisis morfologi menggunakan SEM terlihat bahwa sampel NKEB memiliki permukaan yang tidak beraturan, datar dan berbentuk bongkahan serta terlihat hidroskopis, sedang sampel NKEA memiliki permukaan lebih berpori, sedangkan derajat kristanilitas tidak berhubungan dengan kekerasan tulang hal ini diperlihatkan hasil morfologi sampel BB yang terlihat lebih padat dan keras tetapi memiliki derajat kristanilitas yang rendah.

\section{KESIMPULAN}

Hasil analisis menunjukkan bahwa sampel nanokalsium ekstraksi basa (NKEB) memiliki sifat yang lebih baik dibandingkan sampel bahan baku (BB) dan nanokalsium ekstraksi asam (NKEA) yang ditunjukkan dengan rendemen dan derajat putih yang tinggi, rata-rata ukuran partikel yang relatif lebih kecil, kadar abu yang lebih tinggi dengan kadar kalsium $(20.67 \%)$ dan fosfor $(10.09 \%)$ dengan rasio $\mathrm{Ca} / \mathrm{P}=2.0$. Hasil analisis spektra FTIR menunjukkan bahwa kalsium pada semua sampel merupakan apatit kalsium fosfat amorf dan kristalin. Apatit karbonat tipe $A$ (AKA) terbentuk pada sampel NKEB dan NKEA sedangkan apatit tipe $B(A K B)$ terdapat pada semua sampel kalsium. Analisis XRD menunjukkan bahwa fasa fosfat dan karbonat pada semua sampel merupakan campuran amorf dan kistalin, dengan derajat kristalinitas sampel NKEB lebih tinggi atau lebih kristalin dibandingkan sampel lainnya, hal ini didukung oleh morfologi permukaan sampel NKEB yang halus, datar dan berbentuk bongkahan.

\section{UCAPAN TERIMA KASIH}

Pimpinan beserta jajaran Balai Besar Penelitian dan Pengembangan Pengolahan Produk dan Bioteknologi Kelautan dan Perikanan (BBP4BKP), Kementerian Kelautan dan Perikanan, Jakarta atas bantuan biaya dan fasilitas dalam penelitian.

\section{DAFTAR PUSTAKA}

[AOAC] Association of Official Analytical Chemist. 2005. Official Methods of Analytical of The Association of Official Analytical Chemist. Method: 925.09, 941.12, 920.87, 960.39, 968.08, 948.09. AOAC International, Washington, DC.

Dahlan K, Sari YW, Yiniarti E, Soejoko DS. 2006. Karakterisasi gugus fosfat dan karbonat dalam tulang tikus dengan Fourier transform infrared (FT-IR) spectroscopy. Indonesian J Materials Sci Edisi Khusus Oktober: 221-224.

Dongoran N, Kustiyah L, Marliyati SA. 2007. Pembuatan susu kedelai berkalsium tinggi dengan penambahan tepung tulang ikan kakap merah (Lutjanus Sanguineus). J Media Gizi dan Keluarga 31: 71-79.

Greiner R. 2009. Current and projected of nanotechnology in the food sector. J Nutrire - Revista da Sociedade Brasileira de Alimentação e Nutrição 34: 243-260.

Hemung BO. 2013. Properties of tilapia bone powder and its calcium bioavailability based on transglutaminase assay. Int J Biosci, Biochem and Bioinform 3: 306-309. DOI: 10.7763/IJBBB.2013.V3.219.

Huang YC, Hsiao PC, Chai HJ. 2011. Hydroxyapatite extracted from fish scale: Effects on MG63 osteoblast-like cells. Ceram Int 37: 1825-1831. DOI: 10.1016/j.ceramint.2011. 01.018

Karthikeyan S. 2011. X-ray diffraction and Fourier transform study of toxic effect of heavy metals on bone tissues of an edible fish cirrhinus mrigala. Acta Phys Pol A 122: 236-239.

Kaya AOW, Santoso J, Salamah E. 2008. Pemanfaatan tepung tulang ikan patin (Pangasius $\mathrm{sp}$ ) sebagai sumber kalsium dan fosfor dalam pembuatan biskuit. J Ichtyos 1: 9-14.

Khoerunnisa. 2011. Isolasi dan Karakterisasi Nano Kalsium dari Cangkang Kijing Lokal (Pilisbryoconcha exilis) dengan Metode Presipitasi [Skripsi]. Bogor: Fakultas Perikanan dan IImu Kelautan, Institut Pertanian Bogor.

Kim SK, Mendis E. 2006. Bioactive compounds from marine processing by products - A review. Food Res Int 39: 383393.

Luu PH, Nguyen MH. 2009. Recovery and utilization of calcium from fish bones byproducts as a rich calcium source. Vietnam J Sci and Technol 47: 91-103.

Malde MK, Bugel S, Kristensen M, Malde K, Graff IE, Pedersen JI. 2010. Calcium from salmon and cod bone is well absorbed in young healthy men: a double-blinded randomized crossover design. Nutr Metab 7: 1-9. DOl: 10.1186/1743-7075-7-61.

Mathai M, Takagi S. 2001. Structures of biological minerals in dental research. J Res Nat of Ins Stand Technol 106: 10351044.

Mohanraj VJ, Chen Y. 2006. Nanoparticels - A Review. Trop J Pharm Res 5: 561-573.

Park HS, Ahn J, Kwak HS. 2007. Effect of nanocalcium supplemented milk on calcium metabolisme in 
ovariectomized rats. Asian-August J Anim Sci 20: 12661271.

Park B. 2007. Current and Future Application of nanotechnology. Di dalam: Hester RE, Harrison RM, editor. Nanotechnology: Consequences for Human Health and Environment. Volume 24. Cambridge: Royal Society of Chemistry Publishing, London. DOI: 10.1039/978184 7557766-00001.

Petenuci ME, Stevanato FB, Visentainer JE, Matsushita M, Garcia EE, de Souza NE, Visentainer JV. 2008. Fatty acid concentration, proximate composition, and mineral composition in fishbone of nile tilapia. Arch Latinoam Nutr 58: 87-90.

Phiraphinyo P, Taepakpurenat S, Lakkanatiporn P, Suntornsuk W, Suntornsuk L. 2006. Physical and chemical properties of fish and chicken bones as calcium source for mineral supplements. Songklanakarin J Sci Technol 28: 327-335.

Sittikulwitit S, Sirichakwal PP, Puwastien P, Chavasit V, Sungpuag P. 2004. In vitro bioavailability of calcium from chicken bone extracts powder and its fortified products. $J$ Food Compos Anal 17: 321-329. DOI: 10.1016/j.jfca. 2004.03.023

Suptijah P, Hardjito L, Haluan J, Suhartono MG. 2010.
Recovery dan manfaat nano kalsium hewan perairan (dari cangkang udang). Logika 2: 61-64.

Techochatchawal K, Therdthai N, Khotavivattana S. 2009. Development of calcium supplement from the bone of Nile Tilapia (Tilapia nilotica). Asian J Food Agro-Indy 2: 539-546.

Toya T, Jotaki R, Kato A. 1986. Specimen Preparation in EPMA and SEM. JEOL Training Center EP Section.

Trilaksani W, Salamah E, Nabil M. 2006. Pemanfaatan limbah tulang ikan tuna (Thunnus sp.) sebagai sumber kalsium dengan metode hidrolisis protein. Buletin Teknologi Hasil Perikanan 9: 34-45.

Uskokovic V. 2007. Nanotechnologies: What we do not know. Technol Soc 29: 43-61. DOI: 10.1016/j.techsoc. 2006.10.005.

Vignesh R, Srinivasa M. 2012. Nutritional quality of processed head and bone flours of tilapia (Oreochromis mossambicus, Peters 1852) from Parangipetai estuary, South East Coast of India. Asian Pacific JI Tropl Biomed 2: S368-S372. DOI: 10.1016/S2221-1691(12)60189-0

Venkatesan J, Kim SK. 2010. Effect of temperature on isolation and characterization of hydroxyapatite from tuna (Thunnus obesus) bone. Materials 3: 4761-4772. DOI: 10.3390/ ma3104761. 